\title{
A musculus tensor tympani és a musculus stapedius ín átvágásának hatása a Ménière-betegségben szenvedők életminőségére
}

\author{
Szirmai Ágnes dr. - Maihoub Stefani dr. - Molnár András dr. \\ Fent Zoltán dr. - Tamás László dr. - Polony Gábor dr.
}

Semmelweis Egyetem, Általános Orvostudományi Kar, Fül-Orr-Gégészeti és Fej-Nyaksebészeti Klinika, Budapest

Bevezetés: A musculus (m.) stapedius és a m. tensor tympani (TT) inának átvágása egy minimálinvazív sebészi lehetőség a Ménière-betegség sebészi terápiájában. A feltételezett hatásmechanizmus szerint a tensor tympani medializálja a stapest az ovális ablakban, és ennek, valamint a stapediusínnak az átvágása befolyásolja a belső fül nyomásviszonyait Ménière-betegségben.

Célkitüzés: Dizziness Handicap Inventory (DHI) - szédülésterheltségi skála - és Tinnitus Handicap Inventory (THI) - fülzúgásterheltségi skála - segítségével annak megállapítása, hogy a tenotomia hogyan befolyásolja a Ménièrebetegek életminőségét.

Módszer: Diagnosztizált, egyoldali Ménière-betegeket vizsgáltunk (22 beteg), akik előzetes beleegyezésük után tenotomia mútéten estek át, általános vagy helyi érzéstelenítésben. A betegek a mútét előtt, a mưtét után 3 hónappal és egy évvel töltöttek ki kérdőívet, és beszámoltak betegségük tüneteiról.

Statisztikai analizis: A statisztikai analízis az IBM SPSS V24-es programmal készült. Mivel a vizsgált paraméterek nem mutattak normáleloszlást, nemparametrikus tesztet (Mann-Whitney-féle U-teszt) alkalmaztunk. Szignifikanciaszintnek minden esetben a $\mathrm{p}<0,05$ értéket tekintettük.

Eredmények: A DHI-értékek minden betegben szignifikánsan csökkentek, azaz életminőségük jelentősen javult. Elmondásuk szerint szédüléses rohamaik ritkábbá váltak, rövidültek. A fülzúgás szignifikánsan csökkent. Minden beteg állapotjavulásról számolt be.

Következtetés: Bár a műtét hatásának patomechanizmusa (a stapes medializációjának csökkenése az ovális ablakban) nem teljesen tisztázott, és az utánkövetési idő sem hosszú, a rohamok súlyosságának csökkentésével a tenotomia ígéretes, minimálinvazív sebészi lehetőségnek tűnik a konzervatív terápiára rezisztens, Ménière-betegségben szenvedő betegek életminőségének javításában.

Orv Hetil. 2020; 161(5): 177-182.

Kulcsszavak: Ménière-betegség, életminőség, tenotomia, vertigo

\section{Effect of the stapedius and tensor tympani muscles tenotomy on the quality of life of patients suffering from Ménière's disease}

\footnotetext{
Introduction: Tenotomy of the tendon of the stapedius and tensor tympani (TT) muscles is a minimal-invasive surgical therapeutic procedure in Ménière's disease (MD). It has been assumed that the TT medializes the stapes into the oval window, resulting in changes in perilymphatic pressures of the inner ear. By cutting the tendons of both middle ear muscles, they affect the pressure dynamics by not augmenting this pressure even further.

Aim: The immediate and long-term investigation of the effect of middle ear muscle tenotomy on the quality of life of patients suffering from Ménière's disease, measured by the Dizziness Handicap Inventory (DHI) and the Tinnitus Handicap Inventory (THI).

Method: A follow-up study of 22 patients with definite, unilateral Ménière's disease had undergone tenotomy under general or local anesthesia through an endaural approach. Pre- and postoperative DHI values were compared for all patients.
} 
Statistical analysis: The statistical analysis was completed by using the IBM SPSS V24 software. Since the parameters did not show normal distribution, non-parametric test (Mann-Whitney U test) was used. The significance level was specified as $\mathrm{p}<0.05$.

Results: A statistically significant reduction of DHI scores was noted in all patients. The tinnitus significantly reduced and all of the patients mentioned improved symptoms of MD.

Conclusion: Although the follow-up period is short, and the pathomechanism (decrease of stapes medialization in the oval window) is not exactly clear, tenotomy seems to be a successful promising surgical treatment method with a high reduction of dizziness handicap score in conservative therapy-resistant Ménière's disease.

Keywords: Ménière's disease, quality of life, tenotomy, vertigo

Szirmai Á, Maihoub S, Molnár A, Fent Z, Tamás L, Polony G. [Effect of the stapedius and tensor tympani muscles tenotomy on the quality of life of patients suffering from Ménière's disease]. Orv Hetil. 2020; 161(5): 177-182.

(Beérkezett: 2019. szeptember 12.; elfogadva: 2019. október 16.)

\section{Rövidítések}

DHI = (Dizziness Handicap Inventory) szédülésterheltségi skála; SE RKEB = a Semmelweis Egyetem Regionális, Intézményi Tudományos és Kutatásetikai Bizottsága; THI = $($ Tinnitus Handicap Inventory) fülzúgásterheltségi skála; TT = musculus tensor tympani

A Ménière-betegség az egyik legnehezebben kezelhető belsőfül-betegség. Megjelenésében kifejezetten variábilis, csak a betegek $40 \%$-ában találhatók tartós rohammentes periódusok [1]. A betegek életminőségét leginkább a váratlan időközönként jelentkező szédüléses rosszullétek rontják $[2,3]$. Az elfogadott algoritmusok szerint a kezelés báziseszköze a gyógyszeres kezelés [4], mellyel a betegek nagy része tartósan rohammentessé tehető. A nem rohammentes betegek esetében a terápia következő lépcsôje a nem destruktív intratympanalis kezelés [5], illetve a nem destruktív mútéti beavatkozások. Ezek egyike lehet a musculus (m.) stapedius és a m. tensor tympani (TT) inának átvágása, a tenotomia. Franzés mtsai 2003-ban [6] írták le, hogy a szédüléses rohamok gyakorisága és intenzitása csökken a m. tensor tympani és a m. stapedius inának átvágása után. Loader és mtsai ezt megerősítették, és leírták az életminőség jelentős javulását is $[7,8]$. Egyes szerzők intratympanalis gentamicinkezeléssel egyidejúleg alkalmazták, de a gentamicinkezeléssel együtt alkalmazva nem bizonyult hatékonyabbnak a csak gentamicinnel kezelt csoporttal szemben [9]. Albu és mtsai már egyértelmúen jobbnak ítélték az eredményeket a saccotomián átesett betegek eredményeivel összehasonlítva [10]. A feltételezett hatásmechanizmus szerint a tensor tympani medializálja a stapest az ovális ablakban, és ennek, valamint a stapediusínnak az átvágása befolyásolja a belső fül nyomásviszonyait Méniére-betegségben [8].

Célkitűzésünk az volt, hogy a Dizziness Handicap Inventory (DHI) - szédülésterheltségi skála - [11] és a Tinnitus Handicap Inventory (THI) [12] - fülzúgásterheltségi skála [13] - segítségével megállapítsuk, hogyan befolyásolja a tenotomia a Ménière-betegek életminőségét.

A DHI egy 25 kérdésből álló kérdő́iv, melyben az 'igen' válasz 4 pontot, a 'néha' 2 pontot, a 'nem' 0 pontot ér. A maximálisan elérhető pont 100. Minél magasabb a pontszám, annál rosszabb az életminőség. A 14 pont alatti érték normális életminőséget jelez, a 16 és 34 pont közötti érték enyhe, a 36 és 52 pont közötti érték közepes fokú életminőség-romlásra utal. Az 54 pontnál nagyobb érték a súlyos életminőség-romlás mellett szól. A kérdések tüneti, funkcionális és emocionális kérdésekre oszthatók fel. A DHI-kérdő́ivet magyar nyelvre ugyan még nem validálták, de korábban sikerrel alkalmaztuk a betegek életminőségének meghatározására [14].

Ehhez hasonló a validált fülzúgásterheltségi skála, mely szintén 25 kérdésből áll, a lehetséges válaszok pontozása is a fentiekkel egyező. Az összesített pontszám itt is 0-tól 100-ig terjedhet. Ennek alapján különböző súlyossági fokú életminőség-romlás mérhető: minimális (0-16 pont), enyhe (18-36 pont), közepes (38-56 pont), súlyos (58-76 pont) és katasztrofális (78-100 pont) életminóségromlás-kategóriák állíthatók fel.

Mivel a magyar szakirodalomban a tenotomia hatására vonatkozó közleményt nem találtunk, előzetes eredményeinket közlésre érdemesnek tartjuk.

\section{Módszer}

Klinikánkon részletes szakmai tájékoztatást követően betegeink kezdeményezésére, etikai engedély beszerzése (az etikai engedély száma: SE RKEB 133/2018) után végeztünk tenotomia mútéteket. Betegeink korábban már klinikánkon vagy más intézményben diagnosztizált, konzervatív kezelésre rezisztens, egyoldali Méniére-betegek voltak, akik tenotomia mûtéten estek át, általános vagy helyi érzéstelenítésben. A Ménière-betegség diagnózisa a Bárány Társaság 2015-ben megjelent kritériumrendszere alapján történt [15]. A mútétek mindegyikét ugyanaz a szerző, P. G. végezte. 

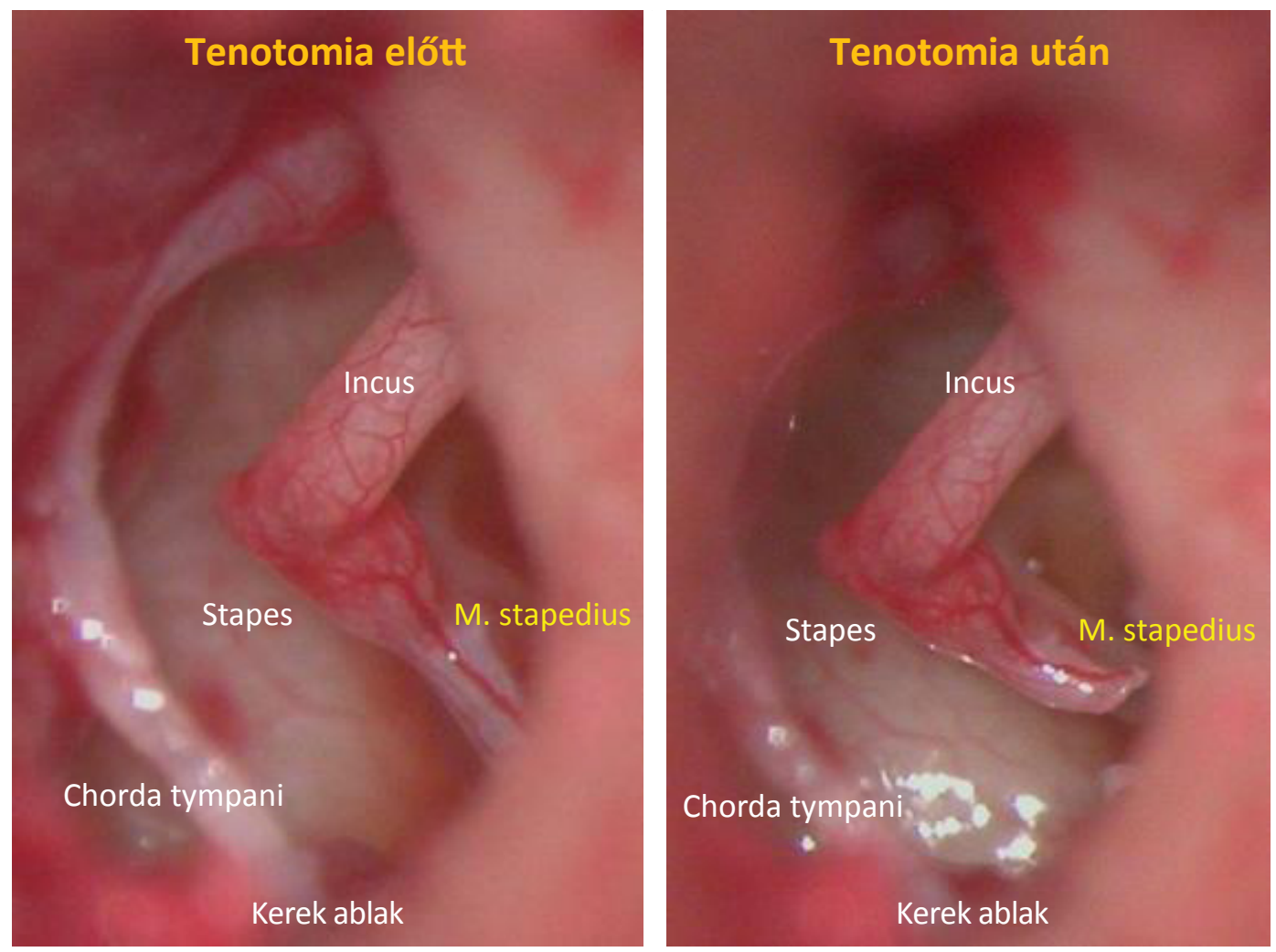

1. ábra

Tenotomia mútét előtt és után. Az ábrán a feltárt dobüregben a m. stapedius ín átvágása előtti és utáni állapot látható. A tensor tympani ina nehezen hozható látótérbe

A műtét minimális kiterjesztésű endauralis metszésből történt. A mütét során átvágásra került a m. stapedius, illetve a $\mathrm{m}$. tensor tympani ina. A tensor tympani ina nehezebben vizualizálható, ezért az intraoperatív felvételen a stapediusín átvágása látható (1. ábra). A betegek néhány órás megfigyelés után vagy - külön kérésre - másnap távoztak. Mintegy 10 nap elteltével történt a varratszedés és a hallójárati tamponok eltávolítása. Az életminőség vizsgálatára a betegek a mütét előtt, a mütét után 3 hónappal és egy évvel töltöttek ki DHI-kérdőívet, és folyamatosan beszámoltak betegségük tüneteiről.

Eddig 22 betegünk esett át tenotomián, 6 férfi és 16 nő. Átlagéletkoruk 44,4 év (a legfiatalabb 29, a legidősebb 74 éves). 11 betegnek a jobb, 11 betegnek a bal füle volt érintett.

A statisztikai analízis az SPSS V24-es programmal (IBM Corporation, Armonk, NY, Amerikai Egyesült Államok) készült. Mivel a vizsgált paraméterek nem mutattak normáleloszlást (Shapiro-Wilk-teszt), nemparametrikus tesztet (Mann-Whitney-féle U-teszt) alkalmaztunk. Szignifikanciaszintnek minden esetben a $\mathrm{p}<0,05$ értéket tekintettük.

\section{Eredmények}

Betegeink között a mütét előtt kitöltött DHI-kérdőív alapján normális életminőségű nem volt. 13\% enyhe, 17\% közepes életminőség-csökkenésről számolt be, míg 70\%-uk a súlyos életminőségcsökkenés-csoportba tartozott. Betegségük egész életvitelüket befolyásolta.

A mútétet követően major szövődményt nem tapasztaltunk. Egy beteg számolt be átmeneti nyelvzsibbadásról, mely kb. 6 hét alatt megszünt. Két betegünknek volt hallójárat-gyulladása a posztoperatív szakban. Egy betegünknek volt egy ízben típusos szédüléses rohama, a többiek közül néhányan időszakos füldugulásról, néhány másodperces bizonytalanságérzésról számoltak be. Egy esetben a kérdőívkitöltés időpontjában enyhe fokú pozicionális nystagmus okozott panaszt, egy betegnél fordult elő egy alkalommal Tumarkin-féle otolithkrízis. Egy betegünknek egyéb alapbetegségei (depresszió, Parkinsonbetegség) befolyásolták a tüneteit. A többi betegünk esetében egyensúly-szabályozást befolyásoló társbetegség nem fordult elö. A betegek a mútét előttihez képest nagyobb mértékű hallásvesztésről nem tettek említést, sőt egy-két betegnél hallásjavulás is bekövetkezett, amit küszöbaudiometriai vizsgálattal tudtunk igazolni.

Három hónappal a mútét után 19 betegünk juttatta el a kérdőívet hozzánk. 32\% normális életminőségről számolt be, enyhe csökkenést tapasztalt a betegeink $42 \%$-a, és közepes csökkenést észleltünk az esetek 16\%-ában. A súlyos életminőségcsökkenés-csoportba már csak betegeink 10\%-a tartozott (a mútét előtt ez 70\% volt). Egy évvel a mütét után eddig 9 betegünk juttatta el hozzánk a kérdőívet. Tenotomián átesett betegeink 33\%-ának életminősége normális volt, $45 \%$ enyhe életminőség- 


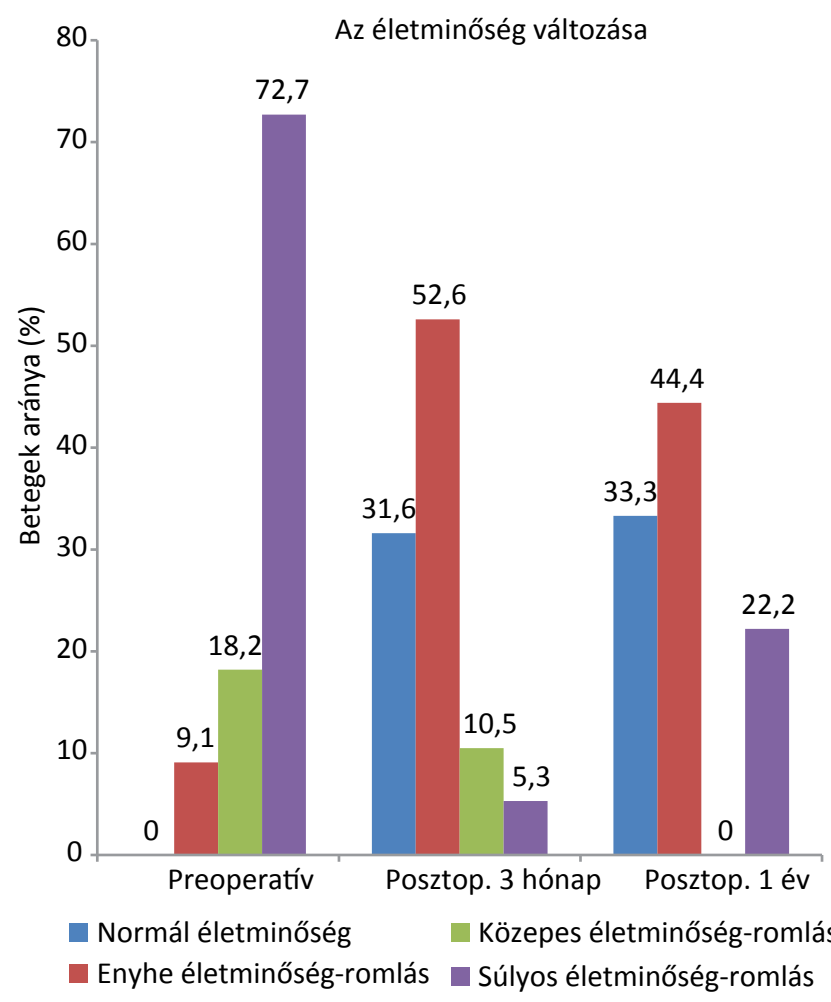

2. ábra

A tenotomiát követően a betegek életminősége javult, 6 betegé normalizálódott, 10 betegé az enyhe romlás kategóriájába került. A súlyosan sérült életminőségű betegek száma nagy mértékben csökkent, egy év alatt 72\%-ról 22\%-ra

csökkenésről számolt be. Közepes életminőség-csökkenés nem volt. Betegeink 22\%-a tartozott a súlyos életminőségcsökkenés-csoportba az egyéves kontrollnál (ebbe a csoportba tartozott a Parkinson-kóros, illetve a Tumarkin-krízises betegünk).
Betegeink javulásának mértékét áttekintve 3 kategóriát javult 4 beteg, akik a súlyos életminőség-romlási kategóriából a normálisba kerültek. 2 kategóriát javult 8 beteg, akik közepes életminőségből a normális kategóriába vagy súlyos életminőség-csökkenésből az enyhe csökkenés kategóriájába kerültek. 6 betegünk esetében egy kategóriát javult az életminőség. Egy betegünk javulása kisebb mértékú volt, így a kategórián belül maradt. A preoperatív DHI-értékhez képest életminőség-romlást nem jelzett egyik betegünk sem (2. ábra).

A 3. ábra mutatja az életminőség pontszámait a mütét előtt és a mütét után 3 hónappal, illetve egy évvel. Látható a mútét utáni pontszámcsökkenés, mely statisztikailag szignifikáns $(\mathrm{p}=0,00016)$. Látható, hogy az életminőség minden kategóriában javult, a teljes DHI-pontszám vonatkozásában az életminőség a súlyos csökkenésból az enyhe csökkenés kategóriájába került. A 3 hónapos és az egyéves eredmények között érdemi különbség nem látható, statisztikailag sem szignifikáns $(\mathrm{p}=0,91)$; ez az eredmények tartóssága mellett szól.

A betegek fülzúgását illetően elmondható, hogy a betegek tinnitusa a mütét előtt a közepes és a súlyos kategória határán lévő életminőség-csökkenést jelzett. Pácienseink elmondása alapján egy betegnek sem lett rosszabb a fülzúgása. A tinnitusterheltségi skála alapján (4. ábra) a betegek fülzúgása szignifikánsan $(\mathrm{p}=0,011)$ csökkent a mútét utáni 3 hónapban, és az enyhe életminőség-csökkenés kategóriájába került. A 3 hónapos és az egyéves eredmények között nincs szignifikáns különbség $(\mathrm{p}=0,13)$

A betegek véleményének ismertetéseként néhány beteg mondatait szó szerint idézzük: „Visszakaptam az életem”, „Ez az új életem a tenotomia után”, „Összehasonlíthatatlan az előtte lévő életemmel, mind fizikailag,

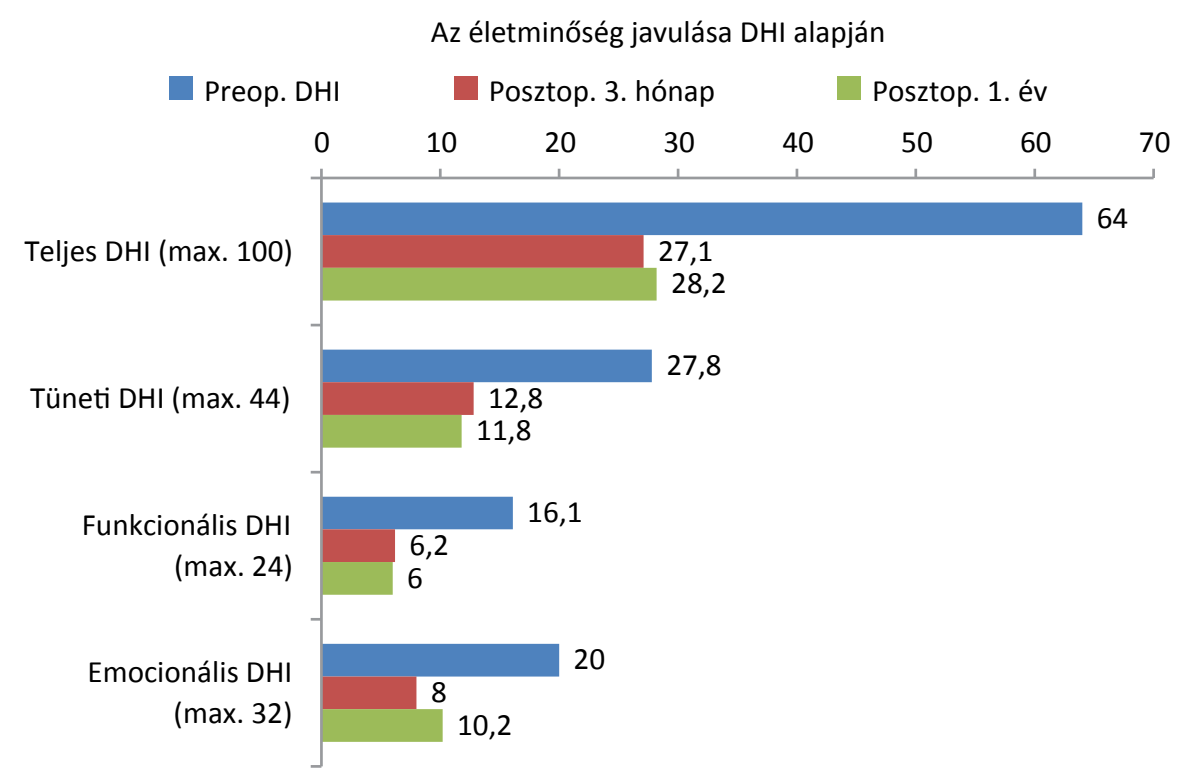

\begin{tabular}{l|l} 
3. ábra & $\begin{array}{l}\text { DHI-értékek tenotomia előtt és után (kérdőívek alapján meghatározott átlag-DHI-értékek). Jól látható a DHI-érték, illetve a részértékek csökkenése } \\
\text { a mútét után. Ez az életminőség javulása mellett szól } \\
\text { DHI = szédülésterheltségi skála }\end{array}$
\end{tabular} 
Fülzúgás javulása tenotomia után

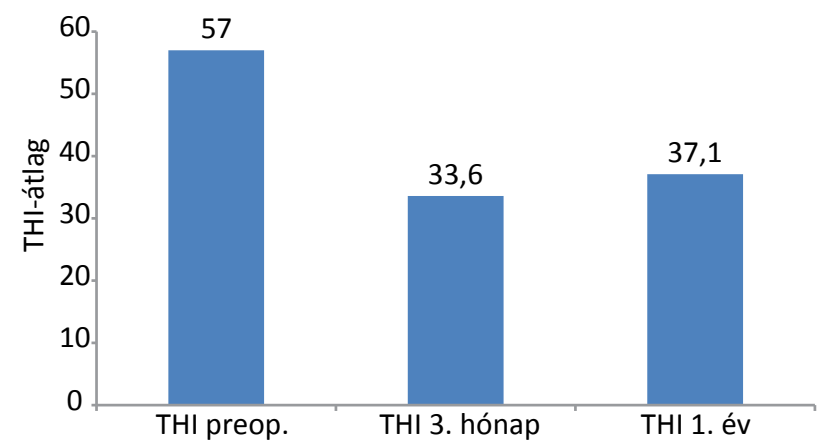

4. ábra

THI-értékek tenotomia előtt és után (kérdőívek alapján meghatározott átlag-THI-értékek). Látható a mútét utáni szignifikáns csökkenés

THI = fülzúgásterheltségi skála

mind pszichésen”. Egy hozzátartozó véleménye: „Amióta megmưtötték, visszakaptuk őt! Az apát, a társat, az életünket!”

\section{Megbeszélés}

A Ménière-betegség nem könnyen kezelhető betegség. A teljes rohammentesség a betegek többségében gyógyszeres kezeléssel elérhető, de sok esetben invazív beavatkozásra van szükség. A minimálinvazív beavatkozások egyike lehet a stapedius, illetve a tensor tympani izmok inának átvágása. Eredményeinket elemezve elmondható, hogy a tenotomián átesett betegek életminősége nagyon rossz volt a mútét elött, és minden betegünk életminősége javult a mútétet követően. A szédülés- és fülzúgásterheltségi skála (DHI és THI) értékei szignifikánsan javultak. A rohamok rövidebbek és enyhébbek lettek a mútét után, ezt mutatják a 3 hónapos eredmények. A 3 hónapos és az l éves eredmények között szignifikáns különbség nincs, ez az eredmények tartóssága mellett szól.

Ez az eredmény megegyezik az irodalmi adatokkal, hiszen a tenotomiát elemző szerzők is javulásról számoltak be. A gentamicinkezeléssel együtt alkalmazott tenotomia jelentős elónnyel nem járt, ez magyarázható azzal, hogy a gentamicinkezelés megszünteti a labyrinthus múködését, és a kiesett múködést már nem befolyásolja egy ilyen kis beavatkozás. Eredményeinket értékelve véleményünk szerint a tenotomia a terápiás lépcsőn a gyógyszeres kezelést követő minimálinvazív sebészi lehetőség lehet, az intratympanalis dexametazon alternatívájaként. Sebészi szempontból a saccotomiával összevetve sokkal kevésbé invazív mútéti eljárás. Mindenképpen meg kell, hogy előzze a szerv múködését megszüntető eljárásokat, az intratympanalis gentamicin adását vagy a labyrinthectomiát.

A tenotomia hatásmechanizmusa még nem tisztázott minden részletében, erre az irodalom sem tér ki. A feltételezett hatásmechanizmus szerint a tensor tympani me- dializálja a stapest az ovális ablakban, és ennek, valamint a stapediusínnak az átvágása befolyásolná a belső fül nyomásviszonyait Ménière-betegségben.

Dolgozatunk limitációja, hogy az utánkövetési idő még rövid, és a patomechanizmus sem tisztázott minden részletében. A hatásmechanizmus további vizsgálata szükséges. A késóbbiekben tervezzük a DHI-kérdőív magyar nyelvre történő validálását, a betegek hosszabb távú utánkövetését, további betegek bevonását és betegeink halláseredményeinek részletes elemzését is. Bár a beavatkozás minimálinvazív jellege a betegeknek panaszt nem okozott, tervezzük a beavatkozást endoszkópos mútét keretei között végezni, ami tovább csökkentheti a betegek megterhelését.

Mindezen limitációk ellenére a rohamok súlyosságának csökkentése, ezáltal az életminőség javítása okán a tenotomia ígéretes lehetőségnek tûnik a Ménièrebetegek életminőségének javításában.

Anyagi támogatás: A kutatómunka anyagi támogatásban nem részesült.

Szerzői munkamegosztás: Sz. Á.: A betegek vizsgálata, gondozása, a cikk megírása. M. S.: Adatfeldolgozás. M. A.: Statisztikai analízis. F. Z.: A betegbevonás koordinálása, kritikai észrevételek. T. L.: Kritikai észrevételek. P. G.: Mütétek végzése, kritikai észrevételek.

Érdekeltségek: A szerző́knek nincsenek érdekeltségeik.

\section{Irodalom}

[1] Walther LE. Procedures for restoring vestibular disorders. GMS Curr Top Otorhinolaryngol Head Neck Surg. 2005; 4: Doc05.

[2] Söderman AC, Bagger Sjöbäck D, Bergenius J, et al. Factors influencing quality of life in patients with Ménière's disease, identified by a multidimensional approach. Otol Neurotol. 2002; 23 : 941-948.

[3] Cohen H, Ewell LR, Jenkins HA. Disability in Meniére's disease. Arch Otolaryngol Head Neck Surg. 1995; 121: 29-33.

[4] Nevoux J, Barbara M, Dornhoffer J, et al. International consensus (ICON) on treatment of Ménière's disease. Eur Ann Otorhinolaryngol Head Neck Dis. 2018; 135(1 Suppl): S29-S32.

[5] Molnár A, Maihoub S, Tamás L, et al. Intratympanically administered steroid for progressive sensorineural hearing loss in Ménière's disease. Acta Otolaryngol. 2019; 139: 982-986.

[6] Franz P, Hamzavi JS, Schneider B, et al. Do middle ear muscles trigger attacks of Menière's disease? Acta Otolaryngol. 2003; 123: 133-137.

[7] Loader B, Beicht D, Hamzavi JS, et al. Tenotomy of the stapedius and tensor tympani muscles reduces subjective dizziness handicap in definite Meniere's disease. Acta Otolaryngol. 2013; 133: 368-372.

[8] Loader B, Beicht D, Hamzavi JS, et al. Tenotomy of the middle ear muscles causes a dramatic reduction in vertigo attacks and improves audiological function in definite Meniere's disease. Acta Otolaryngol. 2012; 132: 491-497.

[9] De Valck CF, Van Rompaey V, Wuyts EL, et al. Tenotomy of the tensor tympani and stapedius tendons in Ménière's disease. BENT 2009; 5: 1-6. 
[10] Albu S, Babighian G, Amadori M, et al. Endolymphatic sac surgery versus tenotomy of the stapedius and tensor tympani muscles in the management of patients with unilateral definite Meniere's disease. Eur Arch Otorhinolaryngol. 2015; 272: $3645-3650$

[11] Jacobson GP, Newman CW. The development of the Dizziness Handicap Inventory. Arch Otolaryngol Head Neck Surg. 1990; 116: 424-427.

[12] Tinnitus Handicap Inventory. [Tinnitus Handicap Inventory kérdő́iv.] Available from: http://semmelweis.hu/fulorrgegeszet/ betegeinknek/jarobeteg-ellatas/fulzugas-ambulancia/tinnitushandicap-inventory-kerdoiv/ [accessed: September 6, 2019]. [Hungarian]
[13] Bencsik B, Tamás L, Trimmel K, et al. Hungarian adaptation of the Tinnitus Handicap Inventory: reliability and validity. Eur Arch Otorhinol. 2015; 272: 2243-2248.

[14] Szirmai Á, Maihoub S, Tamás L. Efficacy of assisted balance training in chronic vestibular vertigo. [Az asszisztált egyensúlyi tréning hatékonysága krónikus vestibularis rendszeri szédülésben.] Orv Hetil. 2018; 159: 470-477. [Hungarian]

[15] Lopez-Escamez JA, Carey J, Chung WH, et al. Diagnostic criteria for Méniére's disease. J Vestib Res. 2015; 25: 1-7.

(Szirmai Ágnes dr., Budapest, Szigony u 36., 1083 e-mail: szirmai.agnes@med.semmelweis-univ.hu)

\section{Pályázati felhívás}

Dr. Fehér János professzornak, a Semmelweis Egyetem II. sz. Belgyógyászati Klinikája volt igazgatójának, az Orvosi Hetilap volt főszerkesztőjének emlékére 2011-ben alapítvány létesült.

A Dr. Fehér János Emlékére Alapítvány fö célja a belgyógyászat, különösen a hepatológia szabad gyökös és immunológiai vonatkozású témaköreinek kutatása, fejlesztése, támogatása, illetve ösztönzése oly módon, hogy az alapítvány kamatából fiatal egyetemi oktatók, $\mathrm{PhD}$-hallgatók és orvostanhallgatók részesüljenek.

\section{A pályázatok benyújtásának határideje: 2020. április 15 .}

A dolgozatot „Dr. Fehér János pályázat” megjelöléssel kell benyújtani, és a pályázathoz mellékelni kell a pályázó önéletrajzát is.

A dolgozatot a Dr. Fehér János Emlékére Alapítvány Kuratóriuma elnökének (Dr. Hagymási Krisztina) vagy titkárának (Dr. Lengyel Gabriella) kell eljuttatni.

Beküldési cím: Semmelweis Egyetem, II. Belgyógyászati Klinika 1088 Budapest, Szentkirályi u. 46.

A díj odaítéléséről a kuratórium dönt. A díj átadására az Orosi Hetilap Markusovszky-ünnepségén kerül sor, ahol a nyertes pályázó 5 perces előadásban foglalhatja össze az eredményeit. 